症例

\author{
食道・胃・直腸の 3 重複癌の 1 例 \\ 神戸赤十字病院外科, 岡山市立せのお病院外科* \\ 野中泰幸津下宏* 湯村正仁
}

今回, われわれは稀な食道・胃・直腸 3 重複癌の 1 例を経験した。症例は 55 歳, 男性. 腹痛と下痢を主訴に来院。大腸内視鏡検查にて上部直腸に全周性高度狭宣を伴う進行癌 を認めた. また術前に上部消化管内視鏡検査を行ったところ, 胃体上部にII C 型早期癌を 認めたため, 低位前方切除術に続いて噴門側胃切除術を行った. 直腸癌術後 1 年 5 力月 の上部消化管内視鏡検查にて胸部食道に 0-IIC 型食道癌を認め, 粘膜切除術を施行し た. その組織学的深達度は $\mathrm{sm}_{2}$ であったため根治手術を萀めたが，手術同意を得られず， 放射線療法を追加施行した。粘膜切除術後 9 力月現在再発の徴候はみられず，外来にて 慎重に経過観察中である。

索引用語：食道・胃・直腸 3 重複癌

\section{はじめに}

検査治療手技の発達, 高齢人口の増加などにより重 複癌症例は近年急速に増加しているが, 食道・胃・直 腸 3 重複癌症例は本邦では稀である. 今回, われわれ は直腸進行癌に胃粘膜癌および食道粘膜下層癌を合併 した 1 症例を経験したので若干の文献的考察を加えて 報告する。

\section{症例}

患者：55歳, 男性.

主訴：腹痛, 下痢.

家族歴：母親に子宮癌。叔母に乳癌. 叔父に胃癌, 大腸癌.

既往歴：特記すべきことなし。

嗜好：ウイスキー水割 $5 \sim 6$ 杯/日, 契煙20本/日 40 年間.

現病歴：平成 10 年 8 月下旬頃より下腹部痛が出現し た。腹痛增強するため同 8 月31日当院内科受診.内視 鏡検査にて上部直腸の全周性高度狭窄を認めたため, 直 腸癌を強く疑い精查加療目的にて 9 月10日入院となった。

入院時現症：身 長 $176 \mathrm{~cm}$, 体 重 $70 \mathrm{~kg}$, 血 圧 $150 / 88$ $\mathrm{mmHg}$, 体温 $36.2^{\circ} \mathrm{C}$. 眼瞼, 眼球結膜に貧血, 黄疸認 めず，腹部平坦で左下腹部に軽度圧痛あり．腫溜は触

2001年 1月31日受付 2001年 4 月 5 日採用

〈所属施設住所〉

テ650-0011 神戸市中央区下山手通 5-6-22
知しなかった。

入院時検査所見：白血球 $8500 / \mathrm{mm}^{3}$, 赤血球 434 万/ $\mathrm{mm}^{3}, \mathrm{Hb} 13.8 \mathrm{~g} / \mathrm{dl}, \mathrm{Ht} 41.4 \%$, 血小板 38.8 万 $/ \mathrm{mm}^{3}$, CRP $10.0 \mathrm{mg} / \mathrm{dl}$, CEA $9.1 \mathrm{ng} / \mathrm{ml}$, その他, 生化学検査 上異常所見はみられなかった。

下部消化管内視鏡検査: 肛門縁より約 $20 \mathrm{~cm}$ の上部 直腸に全周性高度狭窄を認め, 深部への挿入は不可能 であった（図 1)。

上部消化管内視鏡検査 : 胃体上部後壁, 小弯側寄り に $1 \mathrm{~cm}$ 弱の II c 型陥凹性病変を認め, 生検にて高分化 管状腺癌と判明した（図 2 ）.

胸部腹部単純 X 線検查所見：異常所見認めず.

腹部超音波検查所見：肝外側区域 (S 2), 前区域 (S 8)に縗胞を認めた.

腹部造影 CT 検查所見：肝には雃胞を認める以外異 常所見認めず.上部直腸から $\mathrm{S}$ 状結腸にかけて約 $7 \mathrm{~cm}$ にわたる不整壁肥厚を認めた。腹部骨盤㓐内には明ら かなリンパ節腫大は認めなかった。

内視鏡下生検では悪性所見は得られなかったが直腸 癌を強く疑い, 9 月17日, 開腹手術を行った.

手術所見：腹水, 腹膜播種, 肝転移は認めず。腫場 は上部直腸に局在し,一部漿膜面には発赤がみられた。 また右側骨盤後腹膜への痹着あり, 疮着剥離時直腸間 膜側より少量の膿流出を認めた。左結腸動脈を温存しつ つ, 3 群リンパ節郭清を伴う低位前方切除術を施行した。 切除標本所見: $4.5 \times 5.0 \mathrm{~cm}$ 大の 2 型進行癌, 腫瘍 


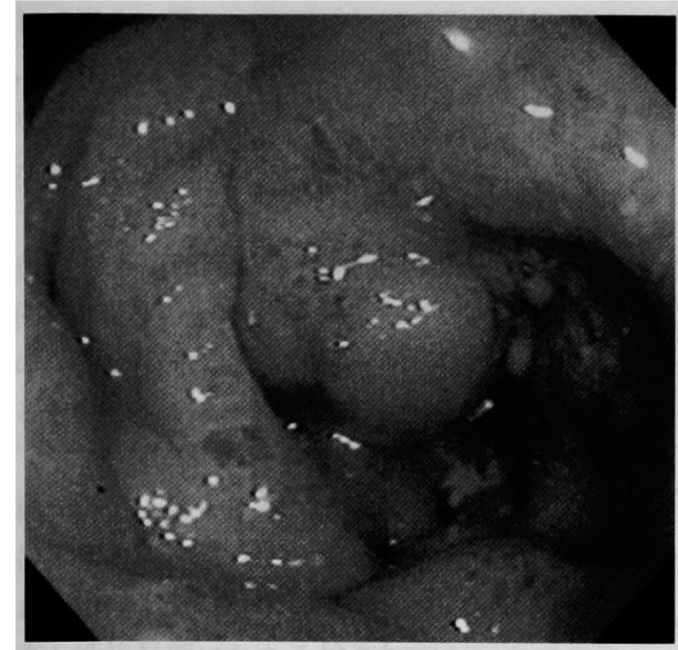

図 1 下部消化管内視鏡検査：上部直腸に全周性高 度狭乍を伴う進行癌を認めた。

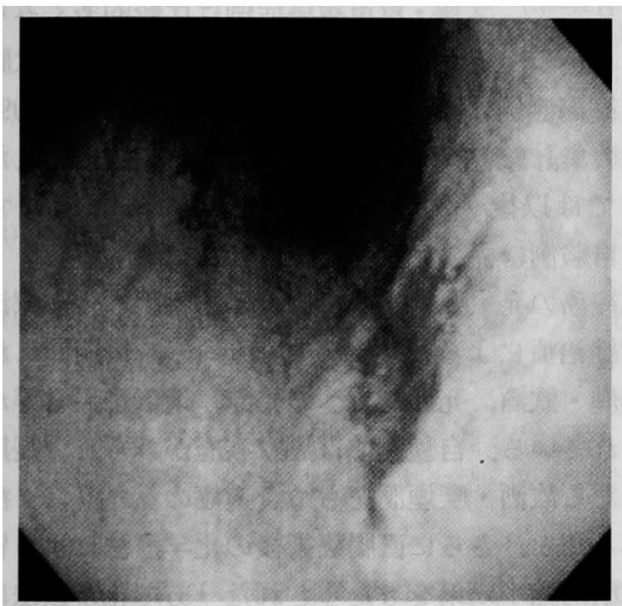

図 2 上部消化管内視鏡検査：胃体上部後壁, 小弯側寄りに $1 \mathrm{~cm}$ 弱の II c 型早期癌を認め た.

直下の 1 群りンパ節腫大を認めた（図 3 ）。

病理組織学的検查所見: 高分化管状腺癌, 深達度ss, Inf $-\beta, \mathrm{ly}_{2}, \mathrm{v}_{0}$, No251の 1 群リンパ節に転移を認めた。 $\operatorname{ssn}_{1(+)} \mathrm{P}_{0} \mathrm{H}_{0} \mathrm{M}(-)$, Stage IIIa, 根治度 A であった. 術後第 $1 ， 2 ， 3$ 病日および 7 病日から11病日にか けて 5-FU 500mg/日の持続静注を行った.

10月13日, 直腸癌術後 1 力月目に IIC 型胃癌に対し 開腹根治手術を行った。

手術所見：漿膜面よりは腫場触知せず,術前マーキン グクリップをたよりに1群リンパ節郭清を伴う噴門側胃 切除術を施行した. 食道残胃端側器械吻合にて再建した。

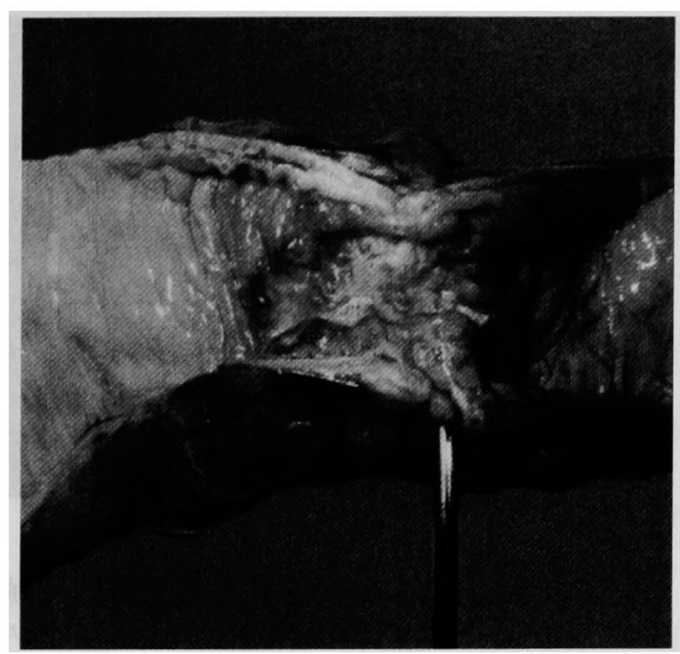

図 3 切除標本所見 : $4.5 \times 5.0 \mathrm{~cm} の 2$ 型直腸進行 癌.

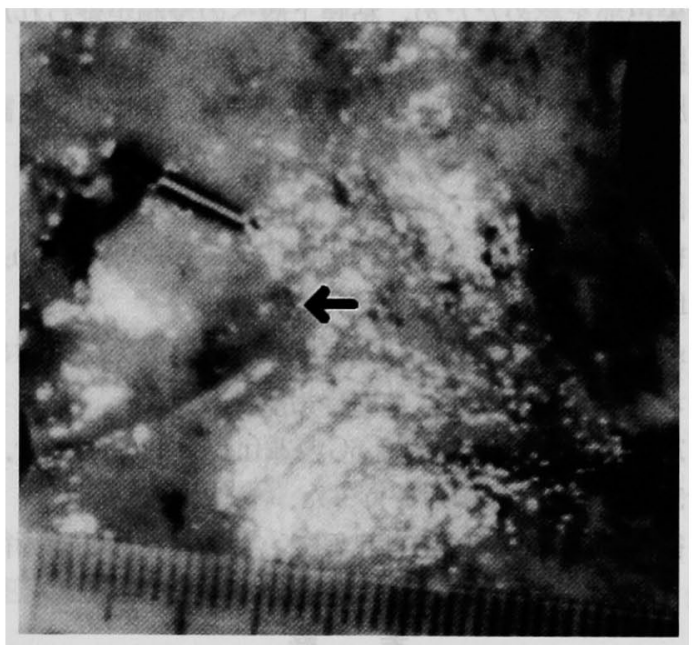

図 4 切除標本所見：胃体上部の IIc 病変は $3 \mathrm{~mm}$ 大と著しく縮小していた。

切除標本所見：直腸癌術後の化学療法のためか, II c 病変は約 $3 \mathrm{~mm}$ 大と著明に縮小していた（図 4 ）.

病理組織学的検查所見: 高分化管状腺癌, 深達度 $\mathrm{m}$, Inf $-\beta, \mathrm{y}_{0}, \mathrm{v}_{0}, \mathrm{n}_{0} . \mathrm{t}_{1} \mathrm{n}_{0} \mathrm{P}_{0} \mathrm{H}_{0} \mathrm{M}_{0}$, Stage I a, 根 治度 Aであった。

以後, 外来にて経過観察加療中, 初回手術より 1 年 5 力月後の上部消化管内視鏡検査にて胸部食道に発赤 を有する不整陥凹性病変を認めた。

食道内視鏡検査所見：門歯列より約 $28 \mathrm{~cm} の$ 胸部食 道後壁に発赤を有し，ルゴール染色にて不染を呈する 不整樎凹性病変あり,生検にて扁平上皮癌と判明した。 


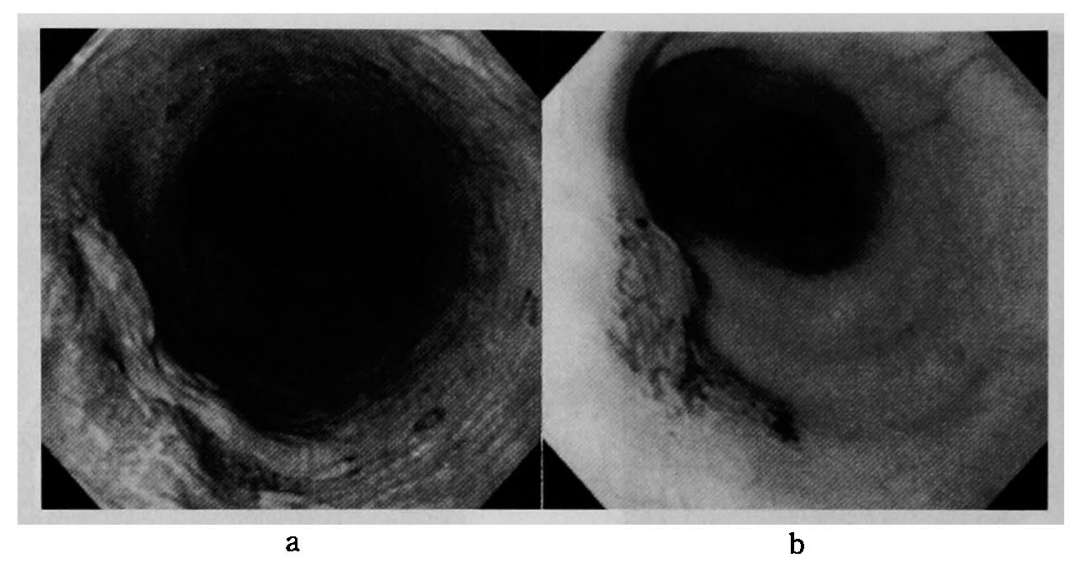

図 5 食道内視鏡検查所見：胸部食道後壁にルゴール染色にて不染带を呈する 0-IIc 食道癌を認めた（a）。トルイジンフルルー染色では網状，一部斑状に染色 された（b).

トルイジンブルー染色では網状に染色され，内部に斑 状染色部を認めたため，粘膜下層への浸潤が疑われた

(図 5 )。

胸部造影 CT 検査所見：肺野, 縦隔に異常所見は認 めなかった。

診断治療目的にて粘膜切除術を施行した。

病理組織学的検查：低分化扁平上皮癌, 深達度 $\mathrm{sm}_{2}$, $\operatorname{Inf}-\beta, 1 y_{1}, v_{0}, \operatorname{margin}(-)$.

$\mathrm{sm}_{2}$ の粘膜下層浸潤を認めたため, 根治手術を勧め たが同意を得られず，放射線治療を行った。

放射線治療：全食道39.6Gy/22fr, 局所 $20 \mathrm{~Gy} / 10 \mathrm{fr}$. 計59.6gy/32fr の照射を行った。

術後経過: 術後経過は良好で, 食道癌粘膜切除術術 後 9 力月現在, 再発の徴候はみられていない.

考 察

重複癌は一般にWarren ら”による定義が用いられ る.すなわち 1) 各腫場は一定の悪性度を示す，2） 各腫湯の発生部位が異なる，3）一方の腫䁑は他方の 転移ではないとするものである。自験例は食道, 胃, 直腸と異なる 3 臟器に発生した癌であり, 胃と直腸は 組織学的に高分化管状腺癌であったが形態的にみてそ れぞれ原発性病変とするのが妥当と思われ， 3 重複癌 と診断した。

近年, 高齢化による癌患者の増加とその治療成績の 向上ならびに診断技術の進歩により, 重複癌症例は急 速に増加してきている。 3 重複癌の発生頻度もまた全 剖検例中, 1993年で0.95\% (306例) と漸次増加してい ることが報告されている2). 大腸癌手術症例の他臓器 重複癌発生頻度は, $10 \%$ 前後と増加傾向にあり ${ }^{3) \sim 61}$, 重
複藏器別では胃癌が $37.8 \%$ - $66.7 \%$ と最も多くを占め

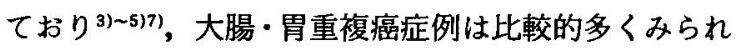
る.しかし、これに食道癌を加えた食道・胃・大腸の 3 重複癌症例に限れば, 本邦では佐々木ら までの集計報告27例に加え，われわれが検索しえたか ぎりでは以後 7 例の報告(例)91 14)がみられるにすぎ ず，自験例は稀な症例と考えられた。

重複癌の発生要因としては遺伝的素因, 化学療法や 放射線治療による宿主免疫力の低下4), 長期間にわた る喫煙・飲酒, 発癌物質への暴露, 遺伝子異常等が考 えられている。自験例では癌家族歴がみられ，長期間 にわたる飲酒・喫煙歴をもつ食道癌のハイリスク症例 であること, さらに直腸癌術後の化学療法により胃癌 に肉眼的縮小効果をもたらされた一方で化学療法に伴 う免疫力低下も否定できないなど, 上記発癌要因が複 雑に関与しているものと考えられた。

重複癌の手術は同時性, 異時性に関わりなく従来開 胸開腹手術が行われてきたが, 近年の内視鏡下手術手 技の発達や早期癌症例の増加により, 粘膜切除術にて 根治が得られる症例が増えてきており ${ }^{11)} ， 3$ 重複癌と もに粘膜切除術にて根治が得られた症例も報告されて いる ${ }^{13)}$. 自験例では食道癌に対して診断的治療として 粘膜切除術を行ったところ, 粘膜下層癌であった。本 来ならばリンパ節郭清を伴う根治開胸開腹手術の絶対 的適応であるが患者本人，家族の強い意向により放射 線治療を選択した.

重複癌の予後は, 大腸癌と他藏器重複癌の検討報告 例において治疮切除例で予後良好とされている が7115，3 重複癌に限ると予後は不良であり，その理由 
として第 2 ,第 3 の癌が進行癌で発見されることが多 く, 先行癌治療の影響で後発癌に対し適切な治療が行 えないことや悪性度の高い食道癌の合併が多いことな どが挙げられている8．食道・胃・大腸の 3 重複癌にお いても同様に予後不良例が多く ${ }^{9)}$, 併存する食道癌の 進行度が予後に最も関連すると考えられている ${ }^{8}$. 自 験例では現在のところ再発の徵候はみられていないが, その予後には同様に食道癌の根治性がもっとも影響を与 えるものと考えられ，今後慎重な経過観察が必要でる。 結 語

稀な食道・胃・直腸の 3 重複癌の 1 例を経験した。 今後, 重複癌症例はますます増加していくことが予想 され，癌症例では重複癌を常に念頭においた術前全身 精査と術後長期にわたる検查加療が必要である.

\section{文献}

1) Warren S, Gates O: Multiple primary Malig. nant tumors, a survey of the literature and a statistical study. Am J Cancer $16: 1358-1414$, 1932

2）松岡正記, 吉田行哉, 早川和雄他：治腹切除しえ た食道, 胃, 大腸の同時性 3 重複早期癌の 1 例. 日消病会誌 $93: 732-737,1996$

3）友田博次, 古澤元之助, 瀬尾洋介他：大腸之他藏 器との重複癌. 外科 $51: 596-599,1989$

4) 久保 章, 伊東重義, 山内 毅: 大腸癌と他臟器 重複癌の検討. 日本大腸肛門病会誌 $45: 1039-$ 1044,1992

5）保田尚邦, 三田村圭太郎, 町田 健他：大腸 - 他 葴器重複癌症例の検討. 日臨外会誌 $60: 2847-$
2850, 1999

6）田中屋宏爾, 小長英二, 竹内仁司：大腸他缄器重 複癌手術例の検討. 日外科系連会誌 $25: 161-$ 165,2000

7）角田明良, 渋沢三喜, 吉沢太人他：大腸と他蔵器 との重複癌の臨床病理学的検討. 日本大腸肛門病 会誌 $46: 282-285,1993$

8）佐々木厚博, 島貫公義, 中谷 武他：食道, 胃, 大腸の同時性早期三重複癌の 1 切除例. 癌の臨 $43: 29-36,1997$

9) 近藤慎治, 谷木利勝, 梅本 淳他：同時性消化器 三重複癌（食道, 胃, 大腸）の切除症例一本邦に おける食道癌を含む三重複癌報告例の検討一。日 臨外医会誌 $56: 1377-1382,1995$

10）浜田邦弘, 横森忠紘, 谷口棟一郎他: 食道, 胃, 直腸に発生した同時性表在型三重複癌のI手術 例. 日臨外医会誌 $57: 987-991,1996$

11）伴登宏行, 山口聖治郎, 笠島史成他: 食道, 胃, 結腸の同時性 3 重複粘膜癌の 1 例. 癌の臨 43 ： 1485-1490, 1997

12）竹重俊幸, 遠藤豪一, 塩豊他：同時性三重複 早期癌の 1 例. 日臨外医会誌 $56: 2740-2743$, 1995

13）村井紀元，村上雅彦，青木武士他：内視鏡下に切 除しえた胃切後同時性異所性三重複癌の 1 例. Progress of Digestive Endoscopy 53:162163,1998

14）内藤善久, 吉住 豊, 愛甲 聡他: 治瘜切除でき た胃・食道・結腸三重複癌の 1 例。埼玉医会誌 $32: 741-743,1998$

15）関根 媇, 須田䔨夫：大腸と他葴器との重複癌の 検討. 日消外会誌 $20 ： 765-771,1987$

\title{
A CASE REPORT OF TRIPLE CANCER OF THE ESOPHAGUS, STOMACH, AND RECTUM
}

\author{
Yasuyuki NONAKA, Hiromu TSUGE* and Masahito YUMURA \\ Department of Surgery, Kobe Red Cross Hospital \\ *Department of Surgery, Okayama Municipal Hospital Seno
}

Triple cancer of the esophagus, stomach, and colorectum is rare. This paper presents such a rare case of triple cancer. A 55-year-old man was seen at the hospital because of abdominal pain and diarrhea. Colonoscopic examination revealed an advanced cancer of the upper rectum with severe stenosis over the entire circumference of the rectum. Routine preoperative endoscopic examination revealed a type 0-IIc cancer at the upper body of the stomach. Low anterior resection (LAR) and a proximal gastrectomy were performed. One year and 5 months after the LAR, an endoscopic examination showed a type 0-IIc cancer in the thoracic esophagus. Endoscopic mucosal resection (EMR) of the esophageal cancer was performed. Histologically, the resected specimen showed cancerous invasion in the submucosa $\left(\mathrm{sm}_{2}\right)$. Adjuvant radiotherapy for the esophagus was performed. The patient has been followed up carefully in the outpatient clinic for 9 months since EMR of the esophageal cancer, with no signs of recurrence. 